LANNA, NBL; SILVA, PNL; COLOMBARI, LF; FREITAS-NAKADA, PG; CARDOSO, AII. 2017. Doses of organic compost on yield and accumulation of macronutrients on endive. Horticultura Brasileira 35: 621-627. DOI - http://dx.doi.org/10.1590/S0102-053620170423

\title{
Doses of organic compost on yield and accumulation of macronutrients on endive
}

\author{
Natália BL Lanna; Priscilla Nátaly L Silva; Lidiane F Colombari; Pâmela G Freitas-Nakada; Antonio Ismael \\ Inácio Cardoso
}

Universidade Estadual Paulista Julio de Mesquita Filho (UNESP), Botucatu-SP, Brasil; nataliabllanna@gmail.com; priscilla_nataly@ hotmail.com; colombarifl@yahoo.com.br; pamelanakada@dracena.unesp.br; ismaeldh@fca.unesp.br

\begin{abstract}
The authors evaluated the effects of doses of organic compost on the production and accumulation of macronutrients in endive plants in two areas with different fertility levels. The experiments were carried out at Fazenda Experimental São Manuel, located in the municipality of São Manuel, São Paulo State, Brazil. The study was carried out in a completely randomized design with seven treatments, six doses of organic compost $(0,35,70,105,140$ and $175 \mathrm{t} / \mathrm{ha})$ and one additional treatment with inorganic fertilizer (N-P-K 4-14-8) and four replicates. In both areas, when the dose of organic compost was increased, the authors noticed a linear increase in fresh matter weight, number of leaves and plant height. In high-fertility area, compared to control (dose 0$)$, using the highest dose $(175 \mathrm{t} / \mathrm{ha})$, the authors observed an increase of 280, 58 and $101 \%$ in fresh matter weight, number of leaves and plant height, respectively. For dry weight, we observed a linear increase in low fertility area and quadratic effect in high fertility area, with maximum estimated dry matter of 22.26 g applying $144 \mathrm{t} / \mathrm{ha}$ of organic compost. The nutrient accumulation was proportional to dry matter, with a linear increase in low fertility area and quadratic effect in high fertility area. The decreasing order of accumulated nutrients was $\mathrm{K}>\mathrm{N}>\mathrm{Ca}>\mathrm{P}>\mathrm{S}>\mathrm{Mg}$, with the highest values, in high fertility area, of 1,269, 471, 185, 91, 53 and $35 \mathrm{mg} /$ plant, respectively, for doses varying from 121 to $158 \mathrm{t} / \mathrm{ha}$.
\end{abstract}

Keywords: Cichorium endivia, soil fertility, plant nutrition.

\begin{abstract}
RESUMO
Doses de composto orgânico na produtividade e acúmulo de macronutrientes em chicória

Objetivou-se com este trabalho, avaliar o efeito de doses de composto orgânico na produção e no acúmulo de macronutrientes em chicória em duas áreas com diferentes níveis de fertilidade. Os experimentos foram conduzidos na Fazenda Experimental São Manuel, localizada no município de São Manuel-SP. O delineamento experimental utilizado foi de blocos ao acaso, com sete tratamentos, sendo seis doses de composto orgânico $(0,35,70,105,140$ e 175 t/ ha) e um tratamento adicional com adubação inorgânica à base do formulado 4-14-8, e quatro repetições. Em ambas as áreas, quando aumentou-se a dose de composto orgânico, houve também um aumento linear no peso da matéria fresca, número de folhas e altura da planta. $\mathrm{Na}$ área de alta fertilidade, em relação ao controle (dose 0), na dose máxima ( $175 \mathrm{t} / \mathrm{ha}$ ) observou-se aumento de 280,58 e $101 \%$ do peso fresco, número de folhas e altura da planta, respectivamente. Para o peso seco, observou-se aumento linear na área de baixa fertilidade e efeito quadrático na área de alta fertilidade, com estimativa máxima de matéria seca em 22,26 g quando aplicados 144 t/ha de composto orgânico. $\mathrm{O}$ acúmulo de nutrientes foi proporcional à matéria seca, com aumento linear na área de baixa fertilidade e efeito quadrático na alta fertilidade. Além disso, a ordem decrescente dos acúmulos pela parte aérea da planta de chicória foi: $\mathrm{K}>\mathrm{N}>\mathrm{Ca}>\mathrm{P}>\mathrm{S}>\mathrm{Mg}$, com valores máximos de 1.269, 471, 185, 91, 53 e $35 \mathrm{mg} /$ planta, respectivamente.
\end{abstract}

Palavras-chave: Cichorium endivia, adubação orgânica, nutrição de plantas.

Received on July 21, 2016; accepted on April 3, 2017

$\mathrm{E}^{\mathrm{n}}$ ndive (Cichorium endivia) is an herbaceous vegetable and belongs to the Asteraceae family. It is similar to lettuce, but more fibrous. This herbaceous plant grows best at temperatures ranging from 20 to $26^{\circ} \mathrm{C}$. Sowing is done generally in autumn and winter. Even though, it can be planted all year long in high elevation area (Ryder, 1998; Filgueira, 2008).

In Brazil, little information is available on endive nutritional requirements (Furlani \& Purquerio, 2010). Therefore, lettuce and other leafy green vegetables are used as reference for endive fertilizer recommendations. However, they are not the same species, and the recommendations could be different. According to Feltrin et al. (2008), nitrogen (N) and potassium (K) are the most extracted nutrients by endive.

Organic and inorganic fertilizers provide necessary nutrients for plants, so it is extremely important to apply fertilizers when cultivating vegetables. In organic systems, producers have been using manure, compost or worm humus (Souza \& Resende, 2014). Organic fertilization increases cation exchange capacity (CEC), nutrient content and soil base saturation (Damatto Junior et al., 2006; Cardoso et al., 2011), and it also optimizes plant nutrients and productivity in several crops. Organic compost shows to be a promising 
alternative which is capable of reducing the application of inorganic fertilizers. Moreover, the importance of studying different doses of organic fertilizer for vegetables in organic systems is indisputable.

Despite the importance of organic fertilizer and its benefits to soil and crop productivity, no studies on endive were found. In lettuce, which belongs to the same family, many researches related that the use of organic matter has increased production and nutrient content (Villas Boas et al., 2004; Yuri et al., 2004; Lopes et al., 2005; Oliveira et al., 2006; Quadros et al., 2012).

Therefore, the present study was carried out to evaluate the effect of different doses of organic compost in the production and macronutrients accumulation of endive in soils with different initial fertility levels.

\section{MATERIAL AND METHODS}

The experiments were carried out at Fazenda Experimental São Manuel, belonging to Faculdade de Ciências Agronômicas of Universidade Estadual Paulista, Botucatu, São Paulo State, Brazil. The local climate, according to Köppen classification, is Cfa type, warm temperate (mesothermal) humid with average annual rainfall of 1,377 mm (Cunha \& Martins, 2009). The average temperature in the hottest month is $22.0^{\circ} \mathrm{C}$ and in the coldest month is $17.5^{\circ} \mathrm{C}$, with average annual temperature of $21^{\circ} \mathrm{C}$ and average annual rainfall of 1,445 mm (Cunha \& Martins, 2009).

Two experiments were carried out in two areas denominated "high" and "low" fertility areas. The soil of both areas is classified as typical dystrophic Red Latosol (Oxisoil) (Embrapa, 2013).

According to soil analysis, "low" fertility area presented: $\mathrm{pH}_{(\mathrm{CaCl} 2)}=5.2$; organic matter $(\mathrm{OM})=9 \mathrm{~g} / \mathrm{dm}^{3} ; \mathrm{P}_{\text {resin }}=$ $0 \mathrm{mg} / \mathrm{dm}^{3} ; \mathrm{H}+\mathrm{Al}=17 \mathrm{mmol} / \mathrm{dm}^{3} ; \mathrm{K}=$ $1.4 \mathrm{mmol}_{\mathrm{c}} / \mathrm{dm}^{3} ; \mathrm{Ca}=16 \mathrm{mmol}_{\mathrm{c}} / \mathrm{dm}^{3}$; $\mathrm{Mg}=4 \mathrm{mmol} / \mathrm{dm}^{3} ; \mathrm{SB}=22 \mathrm{mmol}_{\mathrm{c}} /$ $\mathrm{dm}^{3} ; \mathrm{CEC}=39 \mathrm{mmol} / \mathrm{dm}^{3}$ and $\mathrm{V}=56 \%$. These values show zero phosphorus content, low potassium, high calcium and low magnesium, according to Raij et al. (1997). The "high" fertility area presented: $\mathrm{pH}_{(\mathrm{CaCl} 2)}=5.8 ; \mathrm{OM}=12 \mathrm{~g} /$ $\mathrm{dm}^{3} ; \mathrm{P}_{\text {resin }}=99 \mathrm{mg} / \mathrm{dm}^{3} ; \mathrm{H}+\mathrm{Al}=13$ $\mathrm{mmol}_{\mathrm{c}} / \mathrm{dm}^{3} ; \mathrm{K}=2 \mathrm{mmol} / \mathrm{dm}^{3} ; \mathrm{Ca}=28$ $\mathrm{mmol}_{\mathrm{c}} / \mathrm{dm}^{3} ; \mathrm{Mg}=6 \mathrm{mmol}_{\mathrm{c}} / \mathrm{dm}^{3} ; \mathrm{SB}=$ $36 \mathrm{mmol}_{\mathrm{c}} / \mathrm{dm}^{3} ; \mathrm{CTC}=49 \mathrm{mmol} / \mathrm{dm}^{3}$ and $\mathrm{V}=74 \%$. According to Raij et al. (1997), phosphorus and calcium content can be considered high and potassium and magnesium content are medium in this area. Liming was carried out two months before planting to increase the base saturation to $70 \%$, in the "low" fertility area, as recommended by Trani et al. (1997).

The study was carried out in a completely randomized design, with seven treatments, six doses of organic compost $(0,35,70,105,140$ and $175 \mathrm{t} /$ ha on wet basis, with $31 \%$ humidity) and one additional treatment with inorganic fertilizer and four replicates.

The inorganic fertilization consisted of formulated 4-14-8 (N-P $\mathrm{O}_{5}$ $\mathrm{K}_{2} \mathrm{O}$ ) at doses of 2.85 and $1.45 \mathrm{t} / \mathrm{ha}$ [recommended by Trani et al. (1997) for endive] in "low" and "high" fertility areas, respectively.

We used the organic compost Provaso. Its chemical analysis presented the following characteristics, according to the methodology described by MAPA (2007), given as a percentage of dry matter: $\mathrm{N}=0.5 ; \mathrm{P}_{2} \mathrm{O}_{5}=0.6 ; \mathrm{K}_{2} \mathrm{O}=0.4$; $\mathrm{Ca}=1.4 ; \mathrm{Mg}=0.2 ; \mathrm{S}=0.2 ; \mathrm{U}-65^{\circ} \mathrm{C}=$ 31.0; total $\mathrm{OM}=15.0$; total $\mathrm{C}=8.0$. For every $100 \mathrm{t} / \mathrm{ha}$ of the compost, the authors applied 345, 414 and $276 \mathrm{~kg} / \mathrm{ha}$ of $\mathrm{N}, \mathrm{P}_{2} \mathrm{O}_{5}$ and $\mathrm{K}_{2} \mathrm{O}$, respectively.

Organic compost and formulated fertilizer (4-14-8) were evenly distributed over the seedbeds surface and incorporated with hoes to a depth of $20 \mathrm{~cm}$. This incorporation was carried out five days before seedling transplanting.

The authors used Malan cultivar, sown on May 17, 2013, in polypropylene trays with 200 cells, containing commercial substrate for vegetable seedling production. On June 20, 2013 (i.e. 33 days after sowing). Seedlings were transplanted into 1.2-meter- length seedbeds, in four longitudinal lines and eight plants per line in each plot, spaced $30 \mathrm{~cm}$ between rows and $25 \mathrm{~cm}$ between plants, totalling 32 plants per plot. Only the four plants transplanted into the middle of each plot were evaluated.

Top dressing fertilization was carried out 20 days after the seedling transplanting with $360 \mathrm{~kg} / \mathrm{ha}$ of ammonium sulphate in inorganic fertilizer treatment (Trani et al., 1997) and $750 \mathrm{~kg} /$ ha of castor bean cake in the other six treatments, including control (zero dose of compost), (Silva et al., 2016). The castor bean showed $9 \%$ moisture and $4.79 \%$ of $\mathrm{N}$ in dry matter, which resulted in an application of 36 $\mathrm{kg} / \mathrm{ha}$ of $\mathrm{N}$.

Weed control was carried out using hoes when necessary. In the lack of rainfall, irrigation was daily, about 3 $\mathrm{mm}$, using sprinkler system. The authors did not notice any need for controlling pests and diseases.

Harvest was carried out on August 6, 2013, when the most developed plants occupied completely the area. The evaluated traits were shoot fresh weight and shoot dry matter weight; plant height; number of leaves per plant and accumulation of nutrients in shoots. To obtain dry matter, plants were put in drying chamber with forced-air ventilation at $65^{\circ} \mathrm{C}$ until constant weight.

To determine the amount of accumulated nutrients, the authors used one plant per plot, which was washed before drying. After removing the excess of water, the samples were placed in paper bags, identified and taken into the drying oven with forced-air circulation at $65^{\circ} \mathrm{C}$ until constant weight. After drying, the samples were weighed. Then, each sample was ground in a Wiley mill. After grinding, all samples were taken to Plant Analysis Laboratory, Department of Soil and Environmental Resources, to obtain the contents ( $\mathrm{g}$ / $\mathrm{kg}$ ) of nutrients: nitrogen, phosphorus, potassium, calcium, magnesium and sulphur, according to the methodology described by Malavolta et al. (1997). The amount of extracted nutrients was obtained by multiplying the content of each nutrient by dry matter weight of the sample.

Data were subjected to analysis of variance and regression, to verify the effect of compost doses in the evaluated traits. Joint analysis was also used to compare the two areas, according to 
Banzatto \& Kronka (2006), using F test. To compare organic with inorganic fertilizers treatments, the authors used Dunnett's test ( $5 \%$ probability). Analysis was carried out using Sisvar 5.0 program (Ferreira, 2010), except Dunnett's test, which the authors analyzed using Assistat 7.7 beta program (Silva, 2008).

\section{RESULTS AND DISCUSSION}

\section{Doses of organic compost}

In both areas, when the organic compost dose was increased, the authors noticed a linear increase in fresh matter weight, number of leaves and plant height (Figure 1).

In the "high" fertility area, for each $10 \mathrm{t}$ /ha of organic compost, fresh weight $(16.11 \mathrm{~g})$, number of leaves (1.06) and plant height $(0.60 \mathrm{~cm})$ increased (Figure 1). Compared to control (dose 0), in the highest dose $(175 \mathrm{t} / \mathrm{ha})$ the authors observed an increase of 280,58 and $101 \%$ in fresh weight, number of leaves and plant height, respectively. On the other hand, in the "low" fertility area, for each $10 \mathrm{t} / \mathrm{ha}$ of organic compost, fresh matter (12.75 g), number of leaves $(1.55)$ and plant height $(0.38 \mathrm{~cm})$ increased. Compared to control (dose 0$)$, in the highest dose (175 $\mathrm{t} / \mathrm{ha}$ ) the authors verified an increase of 725,125 and $94 \%$ in fresh weight, number of leaves and plant height, respectively. These high increases, in both soils, demonstrate the importance of application of organic compost for endive production. During the experiment, the average temperature was $18^{\circ} \mathrm{C}$, which is below the ideal temperature for the proper development of endive (i.e. 20 to $26^{\circ} \mathrm{C}$ ), according to Ryder (1998). Even at this temperature, endive has developed in a satisfactory manner, but slower than expected, with a total cycle time of 80 days.

For dry matter production, the authors observed a linear increase in low fertility area, with an increase of $0.70 \mathrm{~g} /$ plant for each $10 \mathrm{t} / \mathrm{ha}$ of organic compost (Figure 1). For the high fertility area, quadratic effect was observed, with the maximum dry matter mass of $22.26 \mathrm{~g}$, for the dose of $144 \mathrm{t} / \mathrm{ha}$ of organic compost. This was due to the fact that the high fertility area presented higher initial amounts of nutrients when compared to the low fertility area. Thus, with lower doses of the compost, the necessity of the plants could have been supplied in the high fertility area and, when using too high doses, the dry matter mass decreased.

Yuri et al. (2004) studied doses of organic compost (0-80 t/ha) on lettuce, which showed significant outcomes for all evaluated traits (fresh matter weight, head circumference and stem diameter) with a quadratic effect for all. They obtained maximum yield by applying $56.0 \mathrm{t} / \mathrm{ha}$ before planting, i.e., much lower dose than the ones used in the present research with endive. However, the compost used in the present study had low values of $\mathrm{N}$ and $\mathrm{K}(0.5 \% \mathrm{~N}$ and $0.4 \% \mathrm{~K}_{2} \mathrm{O}$, both as $\%$ of dry matter), while Yuri et al. (2004) had 1.0\% N and $0.7 \% \mathrm{~K}_{2} \mathrm{O}$. Also Oliveira et al. (2006) had a significant effect of lettuce cultivar Vera in response to top-dressing with poultry litter, reaching maximum production of fresh matter with 23.4 $\mathrm{t} /$ ha. However, poultry litter is richer in nitrogen $(3.5 \% \mathrm{~N})$ and potassium $(3.0 \% \mathrm{~K})$.

Unlike inorganic fertilizers, the mentioned doses of organic fertilizers may not be good enough for a recommendation. It is essentially

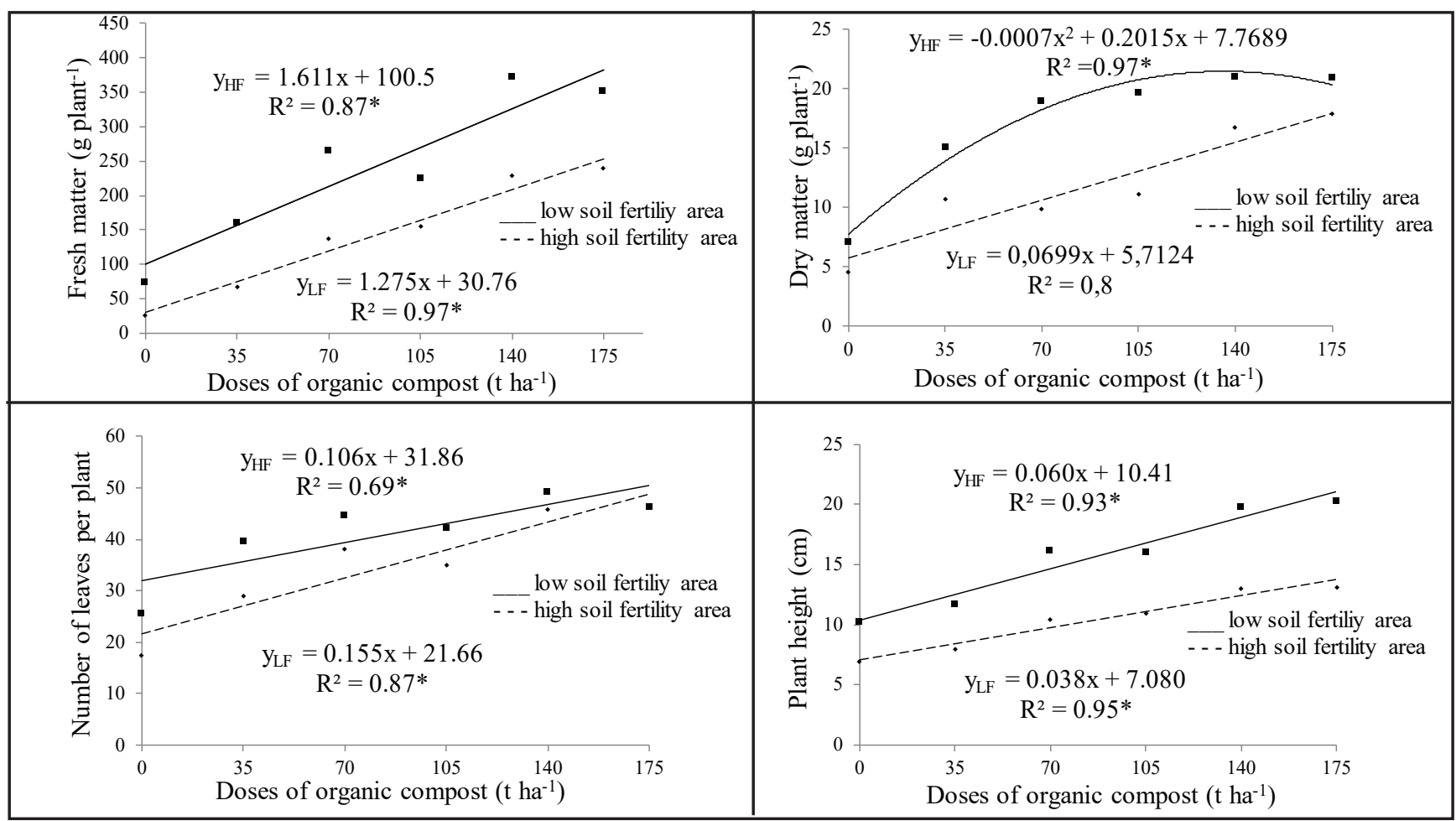

Figure 1. Fresh and dry matter weight, number of leaves, plant height according to different doses of organic compost in the "high" ( $\left.\mathrm{y}_{\mathrm{HF}}\right)$ and "low" $\left(\mathrm{y}_{\mathrm{LF}}\right)$ soil fertility area. São Manuel, UNESP, 2013. 
important to know the fertilizer chemical composition to be able to estimate the amount of each nutrient that is being applied. In the present study, the doses which demonstrated better results for dry matter production were much higher than the highest dose (80 t/ha) recommended by Trani et al. (1997) for endive. In addition, for different amounts of nutrients in organic fertilizer, an official recommendation, described by some cited authors, also include inorganic fertilizer. However, a producer, who only works with organic system, has only organic fertilizers as an option. Whilst, organic fertilizers release nutrients over a fairly long period, being not that immediate as inorganic, which also explains the need for higher doses.

In both areas, some influences of organic compost on the nutrient accumulation of endive could be noticed. In the "low" fertility area, a linear effect for all macronutrients was observed. However, in the "high" fertility area, analysis showed quadratic effect for all macronutrients (Figure 2), which was expected, because accumulation is generally proportional to the dry matter weight, as seen in Figure 1. The increase in accumulation is due to the release of nutrients by organic compost. The soils had low organic matter and in tropical conditions, the decomposition is very fast (Souza \& Resende, 2014), and it is necessary to add organic fertilization in high quantities.

The decreasing order of macronutrients accumulation on endive was $\mathrm{K}>\mathrm{N}>\mathrm{Ca}>\mathrm{P}>\mathrm{S}>\mathrm{Mg}$. However, Feltrim et al. (2008) obtained a different order: $\mathrm{N}>\mathrm{K}>\mathrm{Ca}>\mathrm{Mg}>\mathrm{S}>\mathrm{P}$. In the "high" fertility area, the highest accumulation rates were $1,269,471,185,91,53$, and $35 \mathrm{mg} /$ plant of $\mathrm{K}, \mathrm{N}, \mathrm{Ca}, \mathrm{P}, \mathrm{S}$ and $\mathrm{Mg}$, respectively, with doses of organic compost ranging from 121 to $158 \mathrm{t} /$ ha. Feltrim et al. (2008) had already

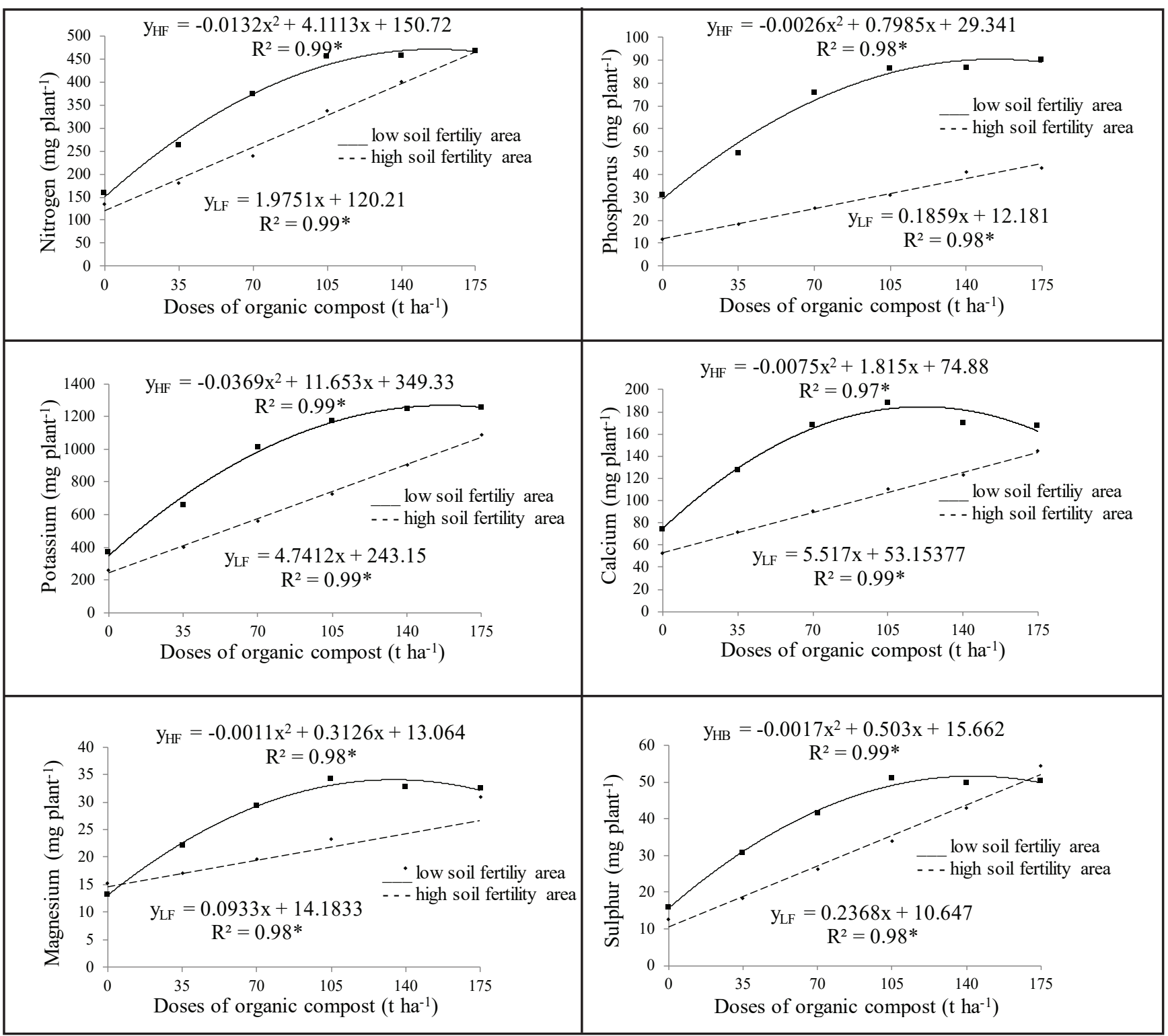

Figure 2. Nitrogen, phosphorus, potassium, calcium, magnesium and sulphur accumulation in endive, according to different doses of organic compost in the "high" $\left(\mathrm{y}_{\mathrm{HF}}\right)$ and "low" $\left(\mathrm{y}_{\mathrm{LF}}\right)$ soil fertility area. São Manuel, UNESP, 2013. 
Table 1. Comparison of organic compost doses with inorganic fertilizer averages for fresh and dry matter weight, height and number of leaves per plant of endive in the "low" and "high" soil fertility areas. São Manuel, UNESP, 2013.

\begin{tabular}{lcccc}
\hline $\begin{array}{l}\text { Doses of organic } \\
\text { compost (t/ha) }\end{array}$ & $\begin{array}{c}\text { Fresh matter } \\
\text { (g/plant) }\end{array}$ & $\begin{array}{c}\text { Dry matter } \\
\text { (g/plant) }\end{array}$ & $\begin{array}{c}\text { Plant height } \\
\text { (cm) }\end{array}$ & $\begin{array}{c}\text { Number of leaves per } \\
\text { plant }\end{array}$ \\
\cline { 2 - 4 } & \multicolumn{4}{c}{ "Low" fertility area } \\
\hline 0 & $27.02^{*}$ & $4.61^{*}$ & $6.97^{*}$ & $17.50^{*}$ \\
75 & $86.54^{*}$ & 10.75 & 7.97 & $29.00^{*}$ \\
70 & $136.45^{*}$ & 9.88 & 10.43 & $38.25^{*}$ \\
105 & $156.10^{*}$ & 11.12 & 10.90 & $35.00^{*}$ \\
140 & 228.26 & 16.74 & 13.00 & 45.75 \\
175 & 239.07 & 17.90 & 13.18 & 46.25 \\
Inorganic fertilizer & 221.04 & 13.66 & 10.94 & 46.25 \\
\hline CV (\%) & 16.82 & 19.74 & 15.22 & 10.40 \\
\hline & & "High" fertility area & $25.50^{*}$ \\
\hline 0 & $75.19^{*}$ & $7.01 *$ & $10.28^{*}$ & 39.50 \\
35 & 161.05 & 15.04 & $11.68^{*}$ & 44.50 \\
70 & 264.13 & 18.89 & 16.25 & 42.25 \\
105 & 225.70 & 19.64 & 16.00 & 49.25 \\
140 & $372.03^{* *}$ & 21.07 & 19.84 & 46.25 \\
175 & 351.01 & 20.87 & 20.34 & 43.25 \\
\hline Inorganic fertilizer & 256.33 & 20.25 & 16.84 & 17.75 \\
\hline CV (\%) & 23.52 & 23.52 & 11.28 & \\
\hline
\end{tabular}

*Statistically lower average than the inorganic fertilizer by Dunnett test at $5 \%$ probability. **Statistically superior average than the inorganic fertilizer by Dunnett test at 5\% probability.

reported total accumulation of 862 , 67, 519, 224, 146 and $90 \mathrm{mg} /$ plant of $\mathrm{N}, \mathrm{P}, \mathrm{K}, \mathrm{Ca}, \mathrm{Mg}$ and $\mathrm{S}$, respectively. In the present study, we obtained higher accumulation of $\mathrm{P}$ and $\mathrm{K}$ compared to that obtained by Feltrim et al. (2008), with emphasis on K values, $247 \%$ higher in the present study. This result is even more significant when comparing to dry matter. In this study, the weight of the maximum dry matter was 21 g/plant, whilst Feltrim et al. (2008) obtained values above $30 \mathrm{~g} /$ plant. A luxury absorption of $\mathrm{K}$ in higher doses of organic compost may have occurred, as it is the fastest nutrient released during mineralization of organic matter (Magro et al., 2010; Cardoso et al., 2011; Quadros et al., 2011). In addition, the lower accumulation of $\mathrm{N}$ in relation to the data reported by Feltrim et al. (2008) should be related to low N content $(0.5 \%)$ in the compost used in this experiment.

\section{Comparison of doses of organic}

\section{compost with inorganic fertilizer}

The authors could observe that in "low" fertility area, the treatment with inorganic fertilizer did not differ from higher doses of organic compost (140 and $175 \mathrm{t} / \mathrm{ha}$ ) for the fresh matter weight and number of leaves per plant (Table 1). However, for plant height and dry matter weight, only the treatment without fertilization $(0 \mathrm{t} / \mathrm{ha})$ showed lower values than the treatment with inorganic fertilizer. In "high" fertility area (Table 1), the authors observed that the absence of fertilization ( $0 \mathrm{t} / \mathrm{ha}$ ) resulted in plants with lower fresh and dry matter weight, plant height and number of leaves per plant when compared to the treatment with inorganic fertilizer. On the other hand, for the highest dose (175 t/ha) of organic compost, plants showed greater fresh matter than the ones with inorganic fertilizer, showing that it is possible to obtain good yields using only organic fertilizer. This result also shows that only inorganic fertilizer at the recommended dose is not enough to obtain the highest weight per plant. So, based in this comparisons, the highest dose can be recommended (175 t/ha) of organic compost to obtain higher fresh weight in endive in both areas, when only organic compost is used.

The values obtained in the best "high" fertility area treatments (Table 1) were similar to those reported by other authors, who also studied endive. Cardoso \& Ustulim Filho (2013), using the same cultivar, obtained an average height of $18.4 \mathrm{~cm}$ and the highest fresh matter of $389 \mathrm{~g}$. For fresh matter, Reghin et al. (2007) obtained 332-407 $\mathrm{g}$, very similar results obtained in this study (372 $\mathrm{g}$ of fresh matter in the best treatments). The values are also similar to those obtained by Feltrim et al. (2006) and Sá \& Reghin (2008).

In the "high" fertility area, only in the treatments with two lower doses ( 0 and $35 \mathrm{t} / \mathrm{ha}$ ), the authors obtained smaller accumulation of $\mathrm{N}, \mathrm{P}, \mathrm{Ca}$, $\mathrm{Mg}$ and $\mathrm{S}$ in relation to the inorganic fertilizer (Table 2). For K, except for the 
Table 2. Comparison of organic compost doses with inorganic fertilizer averages for the accumulation rates of nitrogen, phosphorus, potassium, calcium, magnesium and sulphur in endive in the "low" and "high" fertility areas of the soil. São Manuel, UNESP, 2013.

\begin{tabular}{|c|c|c|c|c|c|c|}
\hline \multirow{2}{*}{ Doses of organic compost (t/ha) } & $\mathbf{N}$ & $\mathbf{P}$ & $\mathbf{K}$ & $\mathbf{C a}$ & Mg & $\mathbf{S}$ \\
\hline & \multicolumn{6}{|c|}{ (mg/plant) } \\
\hline & \multicolumn{6}{|c|}{ "Low"fertility area } \\
\hline 0 & $134.09 *$ & $11.89^{*}$ & $261.94 *$ & $52.39 *$ & $15.27^{*}$ & $12.44^{*}$ \\
\hline 35 & $181.07^{*}$ & $18.51^{*}$ & $402.08^{*}$ & $71.81 *$ & $17.13^{*}$ & $18.43^{*}$ \\
\hline 70 & $238.96^{*}$ & $25.44 *$ & $561.53^{*}$ & 90.18 & 19.63 & $26.21^{*}$ \\
\hline 105 & 337.11 & 30.85 & 728.74 & 110.03 & 23.18 & $34.02 *$ \\
\hline 140 & 399.82 & 41.26 & 905.97 & 122.83 & 27.90 & $42.86^{*}$ \\
\hline 175 & $467.10 * *$ & 42.70 & $1087.77 * *$ & $144.50 * *$ & 30.96 & 54.25 \\
\hline Inorganic fertilizer & 382.76 & 36.21 & 789.23 & 109.74 & 26.49 & 50.69 \\
\hline \multirow[t]{2}{*}{$\mathrm{CV}(\%)$} & 10.66 & 15.82 & 12.36 & 15.67 & 17.93 & 9.74 \\
\hline & \multicolumn{6}{|c|}{ "High" fertility area } \\
\hline 0 & $158.41 *$ & $30.88^{*}$ & $370.43 *$ & $74.39 *$ & $13.21^{*}$ & $15.93^{*}$ \\
\hline 35 & $262.65 *$ & $49.62 *$ & 661.12 & $127.46^{*}$ & $22.16^{*}$ & $30.59 *$ \\
\hline 70 & 373.67 & 75.62 & 1011.96 & 168.35 & 29.20 & 41.66 \\
\hline 105 & 455.58 & 86.29 & 1176.05 & 188.39 & 34.25 & 51.22 \\
\hline 140 & 456.13 & 86.94 & 1250.62 & 170.15 & 32.74 & 49.75 \\
\hline 175 & 467.82 & 90.18 & 1255.70 & 167.46 & 32.57 & 50.30 \\
\hline Inorganic fertilizer & 498.20 & 85.79 & 1067.13 & 200.14 & 32.85 & 53.73 \\
\hline $\mathrm{CV}(\%)$ & 28.56 & 18.33 & 21.89 & 21.72 & 17.63 & 20.94 \\
\hline
\end{tabular}

*Statistically lower average than the inorganic fertilizer by Dunnett test at $5 \%$ probability. $* *$ Statistically superior average than the inorganic fertilizer by Dunnett test at $5 \%$ probability.

Table 3. Average of fresh (FM) and dry matter (DM), plant height (HP), number of leaves per plant (NL) and accumulation of phosphorus $(\mathrm{P})$, potassium $(\mathrm{K})$, calcium $(\mathrm{Ca})$ magnesium $(\mathrm{Mg})$ and sulphur $(\mathrm{S})$ in endive plants in the "high" and "low" soil fertility areas. São Manuel, UNESP, 2013.

\begin{tabular}{|c|c|c|c|c|c|c|c|c|c|}
\hline \multirow{2}{*}{$\begin{array}{l}\text { Initial fertility of } \\
\text { the soil }\end{array}$} & \multirow{2}{*}{$\begin{array}{c}\text { FM } \\
\text { (g/plant) }\end{array}$} & \multirow{2}{*}{$\begin{array}{c}\text { DM } \\
\text { (g/plant) }\end{array}$} & \multirow{2}{*}{$\begin{array}{c}\text { HP } \\
(\mathrm{cm})\end{array}$} & \multirow{2}{*}{ NL } & $\mathbf{P}$ & $\mathbf{K}$ & $\mathrm{Ca}$ & Mg & $\mathbf{S}$ \\
\hline & & & & & \multicolumn{5}{|c|}{ (mg/plant) } \\
\hline "Low" & $142.3 \mathrm{~b}$ & $12.09 \mathrm{~b}$ & $10.4 \mathrm{~b}$ & $35.2 \mathrm{~b}$ & $29.55 \mathrm{~b}$ & $676.7 \mathrm{~b}$ & $100.2 \mathrm{~b}$ & $22.94 \mathrm{~b}$ & $34.13 \mathrm{~b}$ \\
\hline "High" & $241.5 \mathrm{a}$ & $20.02 \mathrm{a}$ & $15.7 \mathrm{a}$ & $41.2 \mathrm{a}$ & $72.19 \mathrm{a}$ & $970.4 \mathrm{a}$ & $156.6 \mathrm{a}$ & $28.14 \mathrm{a}$ & $41.88 \mathrm{a}$ \\
\hline CV (\%) & 20.41 & 30.48 & 13.87 & 12.27 & 21.77 & 20.89 & 20.16 & 17.61 & 19.13 \\
\hline
\end{tabular}

Averages followed by different letters in the columns differ by $\mathrm{F}$ test, $5 \%$.

treatment without fertilization $(0 \mathrm{t} / \mathrm{ha})$, no difference between doses of organic compost and inorganic fertilizer was noticed. Possibly, it occurred because the organic compost had really been a good source of $\mathrm{K}$ for plants, as described by many authors (Damatto Júnior et al., 2006; Magro et al., 2010; Cardoso et al., 2011; Souza \& Resende, 2014).

Despite that lower doses resulted in lower nutrients accumulation in relation to the inorganic fertilizer in the "low" fertility area (Table 2), the highest dose of organic compost (175 t/ha) showed greater accumulation of $\mathrm{N}, \mathrm{K}$ and $\mathrm{Ca}$. This soil presented "low fertility" at the beginning, showing that only inorganic fertilizer was probably not enough to meet the needs of endive.

\section{Comparative analysis of "high" and "low" fertility areas}

For all the traits (fresh and dry matter weight, plant height and number of leaves), regardless of dose, the averages in the "high" fertility area were higher than those in the "low" fertility area (Table 3 ), which confirms the importance of the initial fertility of the soil on endive production.

Villas Boas et al. (2004) studied the influence of different doses of organic compost, in two type of soils [Oxisol (Dark Red Latosoil) (LE), sandy phase, and an Inceptisol (AQ)], on lettuce production. They also presented higher values for fresh and dry matter and number of leaves in the soil (LE) with higher initial fertility levels. According 
to these authors, the recommended dose can vary widely, depending on the species, quality and origin of the organic materials used, soil characteristics, management and climatic conditions. Therefore, as the authors recommend the inorganic fertilization, they also recommended that the amounts of organic fertilizer should be adjusted according to soil fertility. However, Villas Boas et al. (2004) was the only research paper which was found that compares different doses of organic fertilizer in different soils. This study is essential in order to make an accurate recommendation for organic fertilizer.

The authors did not use a joint analysis of nitrogen accumulation, because, according to Banzatto \& Kronka (2006), this is not recommended when the ratio between the mean squares of errors is greater than 7 , as occurred with this nutrient. The average for $\mathrm{N}$ accumulation was 293 and $362 \mathrm{mg} /$ plant in the "low" and "high" fertility areas, respectively. For all other macro nutrients $(\mathrm{P}, \mathrm{K}, \mathrm{Ca}, \mathrm{S}$, and $\mathrm{Mg}$ ) the highest accumulation was obtained in the "high" fertility area, regardless of the treatment in relation to "low" fertility area (Table 3). These results were expected because dry matter in "high" fertility area was greater than in "low" fertility area.

We observed that the higher the dose of organic compost (in the studied range), the higher the endive production (fresh matter) in either "high" or "low" fertility of the soil. In endive, the decreasing order of macronutrients accumulation was: $\mathrm{K}>\mathrm{N}>\mathrm{Ca}>\mathrm{P}>\mathrm{S}>\mathrm{Mg}$.

\section{REFERENCES}

\author{
BANZATTO, DA; KRONKA, SN. 2006. \\ Experimentação Agrícola. 3. ed. Jaboticabal: \\ FUNEP. 237p.
}

CARDOSO, AII; FERREIRA, KP; VIEIRA
JÚNIOR, RM; ALCARDE, C. 2011 Alterações em propriedades do solo adubado com doses de composto orgânico e efeito na qualidade das sementes de alface. Horticultura Brasileira 29: 594-599.

CARDOSO, AII; USTULIN FILHO, AJ. 2013. Produção de chicória em função de doses de nitrogênio e potássio aplicadas na fase de mudas. Horticultura Brasileira 31: 654-658.

CUNHA, AR; MARTINS, D. 2009. Classificação climática para os municípios de Botucatu e São Manuel, SP. Irriga 14: 1-11.

DAMATTO JÚNIOR, ER; VILLAS BÔAS, RL; LEONEL, S; FERNANDES, DM. 2006. Alterações em propriedades de solo adubado com doses de composto orgânico sob cultivo de bananeira. Revista Brasileira de Fruticultura 28: 546-549.

EMBRAPA. 2013. Sistema brasileiro de classificação dos solos. 20 de novembro.

FELTRIM, AL; CECÍlIO FILHO, AB; REZENDE, BLA; BARBOSA, JC. 2006. Produção de chicória em função do período de cobertura com tecido de polipropileno. Horticultura Brasileira 24: 249-254.

FELTRIM, AL; CECÍLIO FILHO, AB; REZENDE, BLA; BARBOSA, JC. 2008. Crescimento e acúmulo de macronutrientes em chicória coberta e não coberta com polipropileno. Horticultura Brasileira 26: 50-55.

FERREIRA, DF. 2010. SISVAR. Versão 5.3. Lavras: Departamento de Ciências Exatas, UFLA.

FILGUEIRA, FAR. 2008. Novo manual de olericultura: Agrotecnologia moderna na produção e comercialização de hortaliças. Viçosa: UFV. 421p.

FURLANI, PR; PURQUERIO, LFV. 2010. Avanços e desafios na nutrição de hortaliças. In: MELLO PRADO, R (ed). Nutrição de plantas: diagnose foliar em hortaliças. Jaboticabal: FCAV/CAPES/FUNDUNESP. p.45-62.

LOPES, JC; RIBEIRO, LG; ARAÚJO, MG; BERALDO, RBS. 2005. Produção de alface com doses de lodo de esgoto. Horticultura Brasileira 23: 143-147.

MAGRO, FO; SALATA, AC; CARDOSO, AII; FERNANDES, DM. 2010. Composto orgânico na produção e qualidade de sementes de brócolis. Ciência e Agrotecnologia 34: 596-602.

MALAVOLTA, E; VITTI, GC; OLIVEIRA, SA. 1997. Avaliação do estado nutricional das plantas, princípios e aplicações. Piracicaba: Potafós. 319p.

MAPA. 2007. Manual de métodos analíticos oficiais para fertilizantes minerais, orgânicos, organo-minerais e corretivos. Instrução
Normativa 28 de 27/07/2007.

OLIVEIRA, NG; POLLI, H; ALMEIDA, DL; GUERRA, JGM. 2006. Plantio direto de alface adubada com "cama" de aviário sobre coberturas vivas de grama e amendoim forrageiro. Horticultura Brasileira 24: 112117.

QUADROS, BR; CORRÊA, CV; CARDOSO, AII. 2012. Influência de composto orgânico e fósforo sobre sementes de alface. Semina 33: 2511-2518.

QUADROS, BR; MAGRO, FO, CORREA A, CV, CARDOSO, AII. 2011. Teor de macronutrientes na parte aérea e sementes de plantas de alface em função de doses de composto orgânico com e sem adição de fósforo ao solo. Semina 32: $1725-1734$

RAIJ, B; CANTARELLA, H; QUAGGIO, JA; FURLANI, AMC. 1997. Recomendações de adubação e calagem para o Estado de São Paulo. Campinas: Instituto Agronômico e Fundação IAC. 285p.

REGHIN, MY; OTTO, RF; OLINIK, JR; JACOBY, CFS. 2007. Produtividade da chicória (Cichorium endivia L.) em função de tipos de bandeja e idade de transplante de mudas. Ciência e Agrotecnologia 31: 739-747.

RYDER, EJ. 1998. Lettuce, endive and chicory. California: CABI Publishing. 208p.

SÁ, GD; REGHIN, MY. 2008. Desempenho de duas cultivares de chicória em três ambientes de cultivo. Ciência e Agrotecnologia 32: 378-384.

SILVA, PNL; LANNA, NBL; CARDOSO, AII. 2016. Produção de beterraba em função de doses de torta de mamona em cobertura. Horticultura Brasileira 34: 416-421.

SILVA, FAS. 2008. Assistat. Versão 7.5., Campina Grande: Assistência estatística, UFCG.

SOUZA, JL; RESENDE, P. 2014. Manual de horticultura orgânica. 3 ed. Viçosa: Aprenda Fácil. 842p.

TRANI, PE; PASSOS, FA; AZEVEDO FILHO, JA.; 1997. Alface, almeirão, chicória, escarola, rúcula e agrião d'água. In: RAIJ, B; CANTARELla, H; QUAGgio, JA; FURLANI, AMC (eds). Recomendações de adubação e calagem para o Estado de São Paulo. Campinas: Instituto Agronômico \& Fundação IAC. p. 168-169.

VILLAS BÔAS, RL; PASSOS, JC; FERNANDES, M; BÜLL, LT; CEZAR, VRS; GOTO, R. 2004. Efeito de doses e tipos de compostos orgânicos na produção de alface em dois solos sob ambiente protegido. Horticultura Brasileira 22: $28-34$.

YURI, JE; RESENDE, GM; RODRIGUES JÚNIOR, JC; MOTA, JH; SOUZA, RJ. 2004. Efeito de composto orgânico sobre a produção e características comerciais de alface americana. Horticultura Brasileira 22: 127-130. 